\title{
Structural Health Monitoring of Japan Bangladesh Friendship Bridge
}

\author{
Md Isteak Reza* \\ * Corresponding Author \\ Bangladesh Army, Bangladesh
}

\author{
Md Manik Mia \\ Assistant Professor, \\ Bangladesh Army International University of Science and \\ Technology (BAIUST), \\ Cumilla Cantonment, Cumilla, Bangladesh
}

\author{
Ashraful Tamjeed \\ Lecturer, \\ Bangladesh Army International University of Science and \\ Technology (BAIUST), \\ Cumilla Cantonment, Cumilla, Bangladesh
}

\begin{abstract}
Structural Health Monitoring (SHM) is a term increasingly used in the last decade whose purpose is to provide us the information regarding the fitness of the structure and to understand their behavior properly. Safety is the most important factor which is needed to consider for any types of infrastructure. SHM is the most significant strategy for ensuring it. Bangladesh has lots of highway bridges since it is a riverine country but it is a matter of regret that SHM system has not implemented yet to any bridges properly. The recent cracks found in Bangabandhu Bridge and Japan Bangladesh Friendship Bridge made the engineers and authorities thinking about SHM system greatly. The main objective of this paper is to design structural health monitoring system for Japan Bangladesh Friendship Bridge. Temperature in Bangladesh fluctuates very much and in order to determine thermal stress, ABAQUS finite element software has been used. Japan Bangladesh Friendship Bridge experienced a great problem regarding local scouring recently and the bridge was closed for one week leading to a great economic loss for the country. So, some threshold values of tiltmeters as warning for local scouring has been calculated finally.
\end{abstract}

Keywords: SHM, Japan Bangladesh Friendship Bridge, local scouring, tiltmeter.

\section{INTRODUCTION}

\section{$1.1 \quad$ General}

Structural health monitoring has been becoming popular day by day in order to monitor civil engineering infrastructures and ensuring safety. Although Bangladesh is a riverine country and bridge plays an important role in national economy, structural health monitoring has not been implemented yet properly for any existing bridges. The present study aims to give some ideas relating temperature and local scour monitoring of Japan Bangladesh Friendship Bridge. The information of Japan Bangladesh Friendship Bridge is given below:

a. Location: 30 kilometers south-east from Dhaka, capital of Bangladesh

b. Type of superstructure: Pre-stressed concrete box girder

c. Total Span Length: 930 meters

d. No of span: 13 e. Date of opening: $1^{\text {st }}$ February 1991

1.2 Objective of the present study

The objective of the present study is to monitor temperature variation through the pre-stressed concrete box girder of Japan Bangladesh Friendship Bridge. The threshold value of tiltmeter placed on top of pier and top of deck in order to monitor local scour monitoring around pier 8 has been studied using the technique implemented in US59 over Guadalupe River Bridge.

\subsection{Methodology of the study}

For studying the temperature variation, ABAQUS 6.13 was be used for investigating thermal stress. After getting these thermal stress, these values were checked against Canadian Highway Bridge Design Code (CHBDC). It has given the idea whether the induced thermal stress has been reached critical or not. Unfortunately, there is no temperature monitoring data available for Japan Bangladesh Friendship Bridge. The temperature monitoring data of Bangabandhu Bridge was used since this bridge is similar to Japan Bangladesh Friendship Bridge and it could be assumed that the temperature fluctuation would be same for these two bridges.

\section{LITERATURE REVIEW}

It has been reported that over 135 bridges in USA partially or totally collapsed during the period of 1989. 2000 (Wardhana et al. 2003). In 2001, the Entre-os-Rios bridge of Portugal collapsed resulting death of 59 people due to scour of a bridge masonry pier (Hansfard et al. 2007). It can be understood very clearly the importance of SHM system for bridges. Some of the bridges having SHM system is described below:

\section{$2.1 \quad$ St. Marx Bridge}

St. Marx Bridge is located in Vienna which is a Pre-stressed concrete box girder bridge. In the year of 1998, a structural health monitoring system in combination with a video control system have been installed to detect heavy vehicle load which may cause structural damage. Four accelerometers and one temperature sensor has been installed. Sensor details are shown in Table 1. 
Table 1. Sensor Details of St. Marx Bridge

\begin{tabular}{|l|l|c|}
\hline Types of sensors & \multicolumn{1}{|c|}{ Number } & Location \\
\hline Accelerometers & 4 channels at 2 sensors per substructure & $\begin{array}{c}\text { At the box girders of the spans } 1 \text { and } 2 \text { (at } 0.6 \times L_{\text {spam }} \text { from } \\
\text { the spam beginning) }\end{array}$ \\
\hline PT100 & 1 at substructure TW5 & At the box girder of the first span (at the beginning) \\
\hline
\end{tabular}

\subsection{I-35W Saint Anthony Falls Bridge}

I-35W Saint Anthony Falls Bridge is located in Minneapolis, Minnesota, USA. It is the replacement for the I-35W Mississippi River Bridge which collapsed in August 1, 2007. It is a Pre-stressed concrete box girder bridge having total length of $370.64 \mathrm{~m}$ (www.structurae.com). A large variety of sensors such as vibrating wire strain gauges, thermistors, linear potentiometers, accelerometers, concrete corrosion and humidity sensors, and SOFO long gauge fibre optic sensors has been used. The sensors are used in all spans but a denser distribution of sensors are used in southbound bridge (Inaudi et al. 2009). This bridge is considered as one of the smart bridges having SHM system applied so extensively. The types of sensors used in I-35W Saint Anthony Falls Bridge has been shown in Table 2.

Table 2. Types of sensors used in I-35W Saint Anthony Falls Bridge (Inaudi et al. 2009)

\begin{tabular}{|l|l|l|}
\hline Sensor Type & Purpose & Addressed risk/uncertainty \\
\hline Vibrate-wire strain gauges & Local static strain & $\begin{array}{l}\text { Concrete shrinkage and creep. Correspondence } \\
\text { with FEM }\end{array}$ \\
\hline & Local curvature & Loss of pre-stress, creep \\
\hline Thermistors & Temperature & Temperature induced deformations \\
\hline Linear Potentiometers & Temperature gradient & Temperature induced strain \\
\hline Accelerometers & Joint movements & $\begin{array}{l}\text { Stuck joints } \\
\text { Anomalous global movements }\end{array}$ \\
\hline & Traffic induced vibrations & $\begin{array}{l}\text { Excessive vibrations } \\
\text { Dynamic amplification }\end{array}$ \\
\hline & Modal Frequencies & Correspondence with FEM \\
\hline Corrosion Sensors & Dynamic damping & $\begin{array}{l}\text { Stuck joints } \\
\text { Anomalous global behavior }\end{array}$ \\
\hline & Corrosion resistivity & Water exchange in concrete deck \\
\hline Long-gauge fiber optic sensor & Corrosion current & Corrosion of concrete deck rebars \\
\hline & Average strains & $\begin{array}{l}\text { Detection of Cracks } \\
\text { Correspondence with FEM }\end{array}$ \\
\hline & Strain distribution & Temperature induced deformations with FEM \\
\hline & $\begin{array}{l}\text { Average Curvature } \\
\text { Deformed Shape }\end{array}$ & $\begin{array}{l}\text { Loss of pre-stress, creep Correspondence with } \\
\text { FEM }\end{array}$ \\
\hline & $\begin{array}{l}\text { Dynamic strains, dynamic deformations, } \\
\text { mode shapes }\end{array}$ & \begin{tabular}{l} 
Anomalous global behavior \\
\hline
\end{tabular} \\
\hline
\end{tabular}

\subsection{Geumdang Bridge of South Korea}

Geumdang Bridge is located in Icheon, South Korea consisting of two structural systems, the northern span consists of concrete deck supported by four pre-cast concrete I-beam sections and the southern span is a continuous concrete box girder supported by three concrete piers. A dense network of wireless sensors were installed with high sensitivity PCB Piezotronics 3801 accelerometer (sensitivity is $0.7 \mathrm{~V} / \mathrm{g}$ ) in order to measure vertical acceleration of the bridge (Swartz et al. 2007). The arrangement of the sensors is shown in Figure 1.

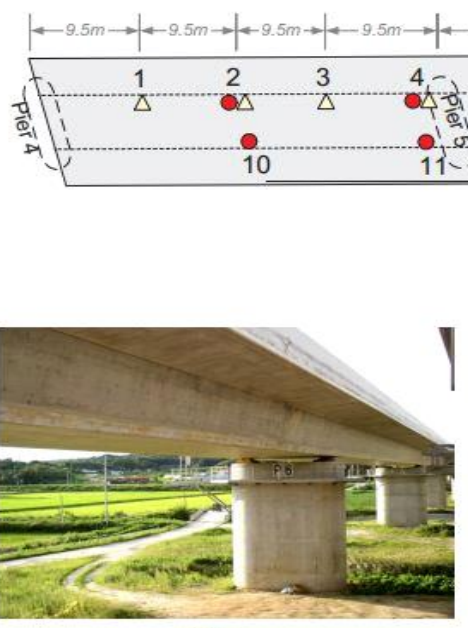

(b)

(a)

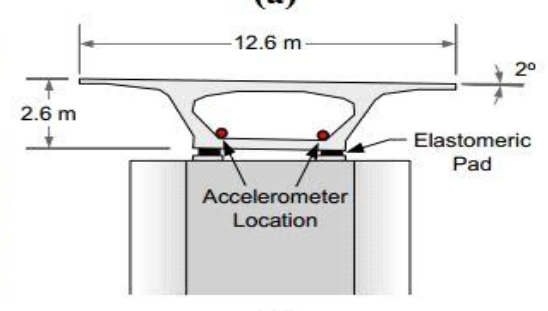

(c)

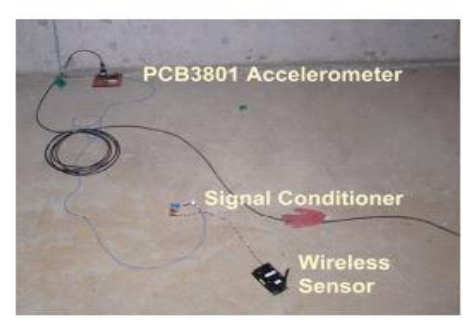

(d)

Figure 1. (a) Location of wireless sensors installed along the length of the Geumdang Bridge; (b) External view of the box girder bridge; (c) Cross-section of the box girder showing the location of accelerometer location; (d) Typical wireless sensor-accelerometer installation (Wang et al. 2007) 


\subsection{Jinghang Canal Bridge (JCB)}

Jinghang Canal Bridge is located in China and it is a pre-stressed concrete single cell box girder bridge having main span of $150 \mathrm{~m}$. The items such as temperature, strain of reinforcement, deflections are used for long-term monitoring. To minimize the cost of the long-term monitoring system, vibrating strain gauges with built-in temperature couples were embedded in the bridge. The hydrostatic levelling system were used for long-term deflection monitoring and eight cross-sections were used such as sections Z2 and Z3, sections A1 to A4, sections B1 and B2. Each DT were installed on the inner surface of the web of the box girder. It is found that strain increment is insignificant at main span support indicating that concrete shrinkage or creep is not significant in that location. But at mid-span of main span the effect has been found significant. It has been found that the measured time dependent deflections are larger than the design values indicating that deflection at mid-span is one of the main problems of pre-stressed concrete bridge. The sensor layout for the monitoring in construction, completion test and service stages are shown in the Figure 2.

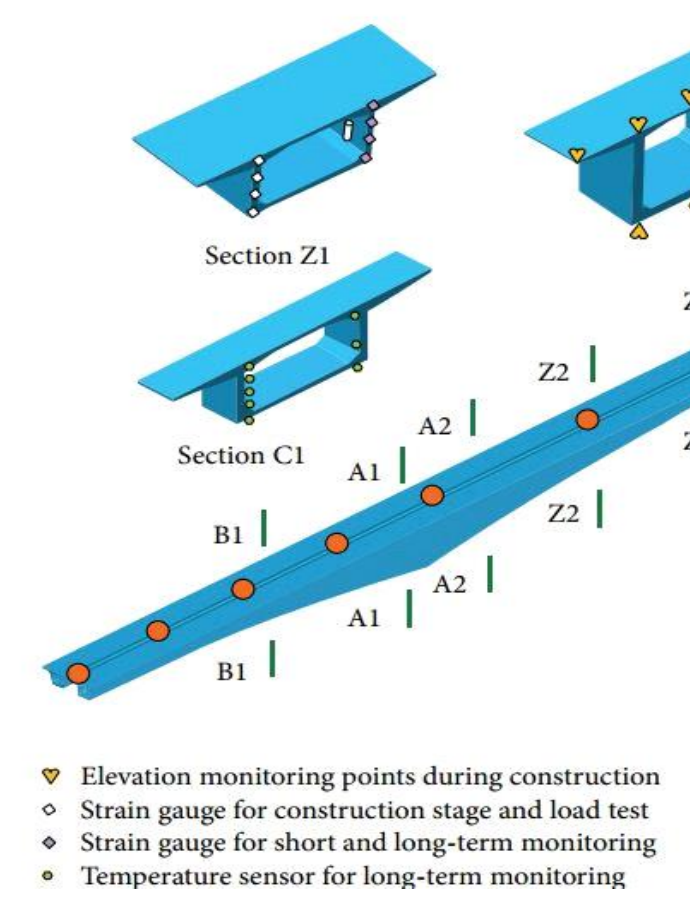

$$
\text { service stages are shown in the Figure } 2 .
$$

Figure 2. Sensor layout of Jinghang Canal Bridge (Chen et al. 2014)

\subsection{Bangabandhu Bridge}

Bangabandhu Bridge is located in Bangladesh which is a pre-stressed concrete box girder bridge. The total length is $4.8 \mathrm{~km}$ having main span $100 \mathrm{~m}$. In 2014 , approximately 147 million USD has been spent to repair cracks on the deck surface. It has been reported that due to

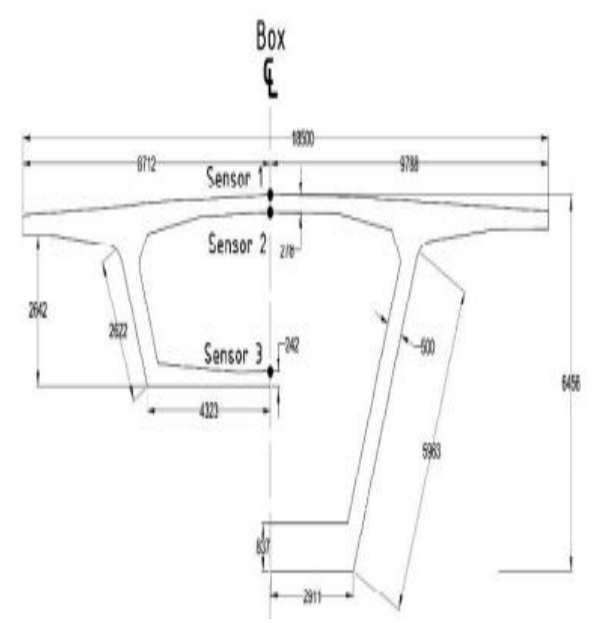

temperature variation of upper and bottom part, these cracks had been occurred (Amin et al.2014). To monitor temperature variation of upper and bottom part, temperature sensors had been used to get data periodically. The arrangement is shown in Figure 3.

Figure 3. Location of sensors to monitor temperature variation in box girder in Bangabandhu Bridge (Amin et al. 2015) Monitoring items of pre-stressed concrete box girder bridges all over the world is shown in the Table 3 . 
Table 3. Sensors used in different notable pre-stressed concrete box girder bridges of the world (Chen et al. 2014)

\begin{tabular}{|c|c|c|c|c|c|c|c|c|c|c|}
\hline Bridge name & Strain & $\begin{array}{l}\text { Deflection } \\
\text { or rotation }\end{array}$ & $\begin{array}{c}\text { Support } \\
\text { displacement }\end{array}$ & $\begin{array}{c}\text { Acceleration } \\
\text { or velocity }\end{array}$ & Corrosion & Crack & $\begin{array}{c}\text { Prestress } \\
\text { loss }\end{array}$ & $\begin{array}{l}\text { Traffic } \\
\text { camera }\end{array}$ & Temperature & $\begin{array}{l}\text { Weather } \\
\text { station }\end{array}$ \\
\hline $\begin{array}{l}\text { Ferriby Road } \\
\text { Bridge (UK) }\end{array}$ & & $\sqrt{ }$ & & & & $\sqrt{ }$ & & & & \\
\hline $\begin{array}{l}\text { PI-57 Bridge } \\
\text { (France) }\end{array}$ & & & & $\sqrt{ }$ & & & & & $\sqrt{ }$ & \\
\hline $\begin{array}{l}\text { Leziria Bridge } \\
\text { (Portigal) }\end{array}$ & $\sqrt{ }$ & $\sqrt{ }$ & $\sqrt{ }$ & & & & & & $\sqrt{ }$ & \\
\hline $\begin{array}{l}401 \text { Southbound } \\
\text { Bridge (USA) }\end{array}$ & $\sqrt{ }$ & $\sqrt{ }$ & $\sqrt{ }$ & & & & $\sqrt{ }$ & & $\sqrt{ }$ & \\
\hline $\begin{array}{l}\text { California Pilot } \\
\text { Bridge (USA) }\end{array}$ & $\sqrt{ }$ & $\sqrt{ }$ & & $\sqrt{ }$ & & & & $\sqrt{ }$ & $\sqrt{ }$ & \\
\hline $\begin{array}{l}\text { Utah Pilot Bridge } \\
\text { (USA) }\end{array}$ & $\sqrt{ }$ & $\sqrt{ }$ & & $\sqrt{ }$ & & & & $\sqrt{ }$ & $\sqrt{ }$ & $\sqrt{ }$ \\
\hline $\begin{array}{l}\text { Kishwaukee Bridge } \\
\text { (USA) }\end{array}$ & $\sqrt{ }$ & & & $\sqrt{ }$ & & $\sqrt{ }$ & & & $\sqrt{ }$ & \\
\hline $\begin{array}{l}\text { New 135W Bridge } \\
\text { (USA) }\end{array}$ & $\sqrt{ }$ & $\sqrt{ }$ & $\sqrt{ }$ & $\sqrt{ }$ & $\sqrt{ }$ & & & & $\sqrt{ }$ & \\
\hline $\begin{array}{l}\text { Kamikazue Viaduct } \\
\text { (USA) }\end{array}$ & & & & & & & $\sqrt{ }$ & & & \\
\hline $\begin{array}{l}\text { A curved Bridge } \\
\text { (USA) }\end{array}$ & & $\sqrt{ }$ & & $\sqrt{ }$ & & & & & $\sqrt{ }$ & \\
\hline $\begin{array}{l}\text { West street On- } \\
\text { ramp Bridge (USA) }\end{array}$ & & & & $\sqrt{ }$ & & & & & & \\
\hline $\begin{array}{l}\text { North Halawa } \\
\text { valley Viaduct } \\
\text { (USA) }\end{array}$ & & $\sqrt{ }$ & $\sqrt{ }$ & & & & & & & \\
\hline $\begin{array}{l}\text { Zhaoqing Xiajiang } \\
\text { Bridge (China) }\end{array}$ & $\sqrt{ }$ & & & & & & & & $\sqrt{ }$ & \\
\hline $\begin{array}{l}\text { Chongqing } \\
\text { Shibanpo Bridge } \\
\text { (China) }\end{array}$ & $\sqrt{ }$ & $\sqrt{ }$ & & & & & & & $\sqrt{ }$ & \\
\hline $\begin{array}{l}\text { Xushuigou Bridge } \\
\text { (China) }\end{array}$ & $\sqrt{ }$ & $\sqrt{ }$ & & & & & & & $\sqrt{ }$ & \\
\hline $\begin{array}{l}\text { Jiangin Yangize } \\
\text { River Highway } \\
\text { Bridge (China) }\end{array}$ & $\sqrt{ }$ & $\sqrt{ }$ & & & & $\sqrt{ }$ & & & $\sqrt{ }$ & \\
\hline $\begin{array}{l}\text { Anwen Bridge } \\
\text { (China) }\end{array}$ & & $\sqrt{ }$ & & & & & & & $\sqrt{ }$ & \\
\hline $\begin{array}{l}\text { Monitored items in } \\
\text { total }\end{array}$ & 10 & 12 & 4 & 7 & 1 & 3 & 2 & 2 & 13 & 1 \\
\hline
\end{tabular}

\section{METHODOLOGY}

\subsection{Introduction}

Temperature is a very important factor in case of Bangladesh bridges. Significant cracks were observed in

(a)

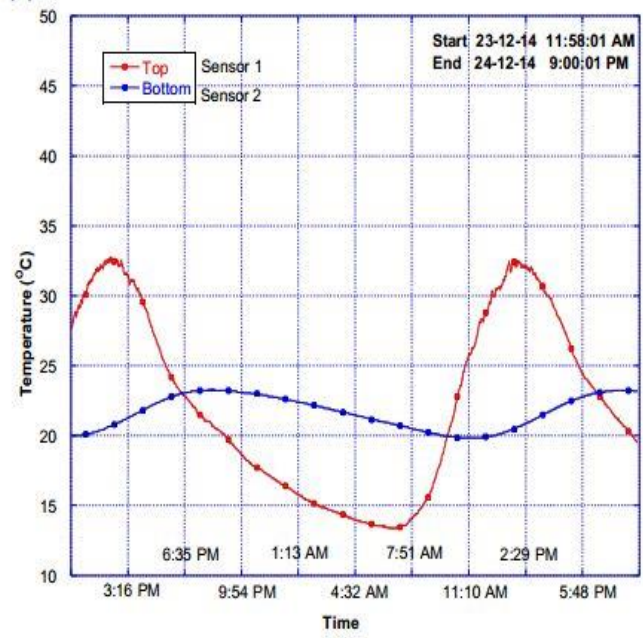

several bridges of Bangladesh i.e. Bangabandhu Bridge (total length $5.63 \mathrm{Km}$ ) and Gabkhan bridge (toatal length $918 \mathrm{~m})$ due to temperature variation. Figure 4 shows the temperature variation of Bangabandhu Bridge which is a box girder type at winter and summer.

(b)

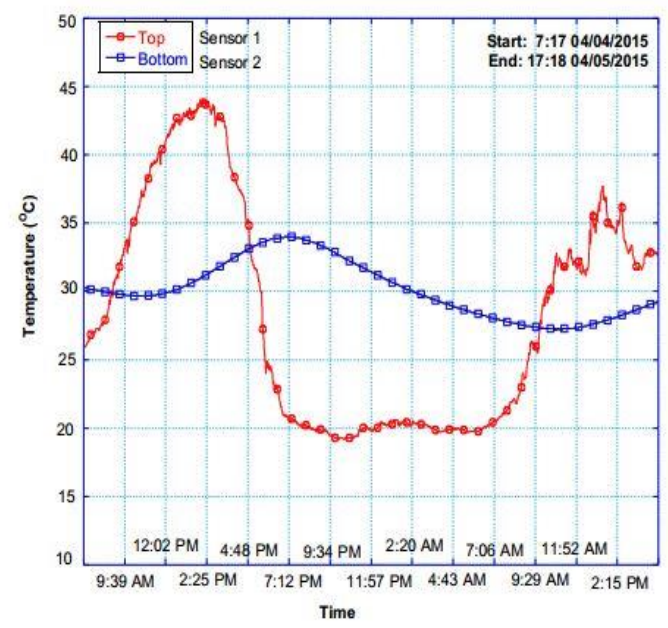

Figure 4. Typical temperature measurement at (a) in winter, (b) in summer 
From the above figure, it is clear to us that a thermal stress reversal occurs at day and night. The intensity of stress reversal is more prominent during summer days when the deck suddenly cools down due to raining creating a temperature gradient about $15^{\circ} \mathrm{C}$. Moreover, hail storm occurs at the starting of summer season in Bangladesh which creates a big problem. During a hail storm, the deck even cools down more rapidly than the bottom part of it creating a worsen condition. It has been reported by Amin et al. (2015) that a hail storm can reduce the ambient temperature by about $12^{\circ} \mathrm{C}$ creating a temperature gradient of around $25^{\circ} \mathrm{C}$. These temperature fluctuation can create a thermal stress leading cracks in the deck.

\subsection{Temperature Monitoring Data}

It has been reported earlier that there is no temperature monitoring data available for Japan Bangladesh Friendship Bridge. So, the temperature monitoring data of Bangabandhu Bridge would be used for thermal stress analysis because Bangabandhu Bridge is located only 120 Kilometers from Dhaka and it could be assumed that temperature fluctuation is same for both regions. Table 4 is showing maximum and minimum temperature distribution along the box girder taken from Figure 4 for Japan Bangladesh Friendship Bridge.

\begin{tabular}{|c|c|c|c|c|c|}
\hline \multicolumn{2}{|c|}{ Table } & \multirow{2}{*}{\multicolumn{2}{|c|}{$\begin{array}{r}\text { um temperature } \\
\text { TOP SURFACE }\end{array}$}} & \multirow{2}{*}{\multicolumn{2}{|c|}{$\begin{array}{l}\text { gladesh Friendship Bridge } \\
\text { BOTTOM SURFACE }\end{array}$}} \\
\hline CASE & DATE \& TIME & & & & \\
\hline CASE 1 & $\begin{array}{l}14.25 \mathrm{pm} \\
4 \text { April’2015 } \\
\text { Summer }\end{array}$ & $44^{\circ} \mathrm{C}$ & $317 \mathrm{~K}$ & $31^{\circ} \mathrm{C}$ & $304 \mathrm{~K}$ \\
\hline CASE 2 & $\begin{array}{l}21.34 \mathrm{pm} \\
\text { 4 April'2015 } \\
\text { Summer }\end{array}$ & $19^{\circ} \mathrm{C}$ & $292 \mathrm{~K}$ & $33^{\circ} \mathrm{C}$ & $306 \mathrm{~K}$ \\
\hline CASE 3 & $\begin{array}{l}15.10 \mathrm{pm} \\
23 \text { December'2014 } \\
\text { Winter }\end{array}$ & $33^{\circ} \mathrm{C}$ & $306 \mathrm{~K}$ & $21^{\circ} \mathrm{C}$ & $294 \mathrm{~K}$ \\
\hline CASE 4 & $\begin{array}{l}7.51 \text { am } \\
24 \text { December'2014 } \\
\text { Winter }\end{array}$ & $13^{\circ} \mathrm{C}$ & $286 \mathrm{~K}$ & $21^{\circ} \mathrm{C}$ & $294 \mathrm{~K}$ \\
\hline
\end{tabular}

In order to calculate thermal gradient, the maximum temperature and minimum temperature had been taken at a same time.

\subsection{Description of the Model}

The following information has been used for model:
a. Span length $=40 \mathrm{~m}=40000 \mathrm{~mm}$
b. Depth of box girder $=2100 \mathrm{~mm}$
c. Thickness of slab $=225 \mathrm{~mm}$
d. Deck width $=9000 \mathrm{~mm}$
e. Modulus of elasticity $=30000 \mathrm{MPa}$

Figure 5 and Figure 6 shows the cross-section and longitudinal section respectively.

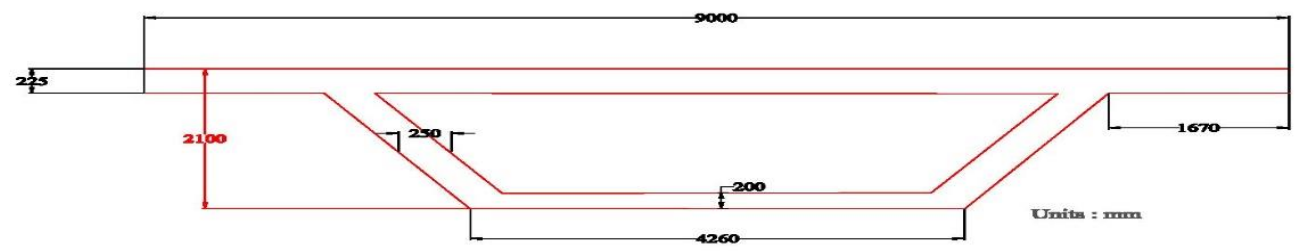

Figure 5. Cross-section of the model 

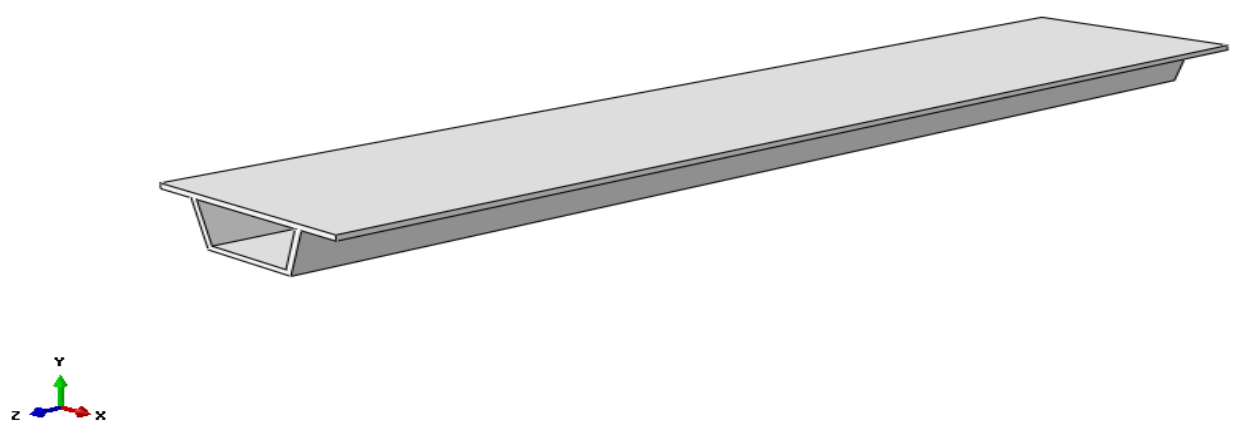

Figure 6. Longitudinal section of the model

\subsection{Finite Element Modelling of the Problem}

There are different finite element packages available but for thermal analysis, ABAQUS 6.13 software had been used. Solid deformable element and coupled temp - displacement procedure had been used for simulation. In order to reduce analysis time, a coarse mesh had been used. The 3-D mesh and boundary condition of the finite element problem is shown in Figure 7 and Figure 8 respectively.
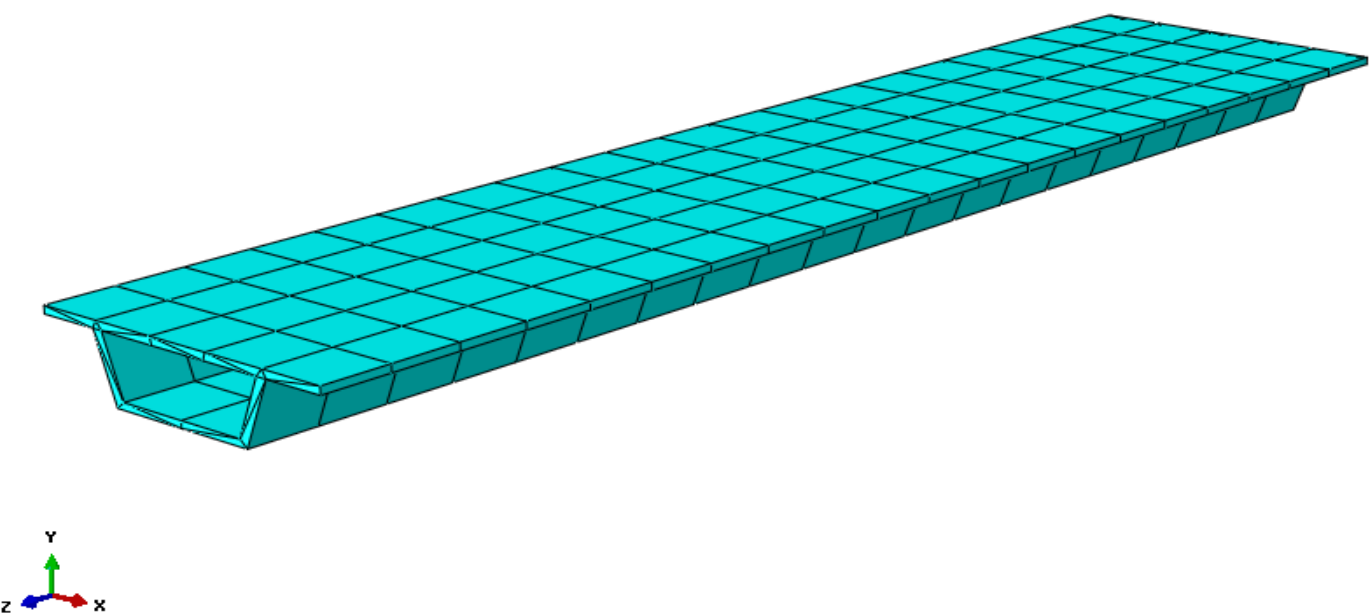

Figure 7. 3-D mesh of the finite element model

The boundary condition applied for the model has been shown below:

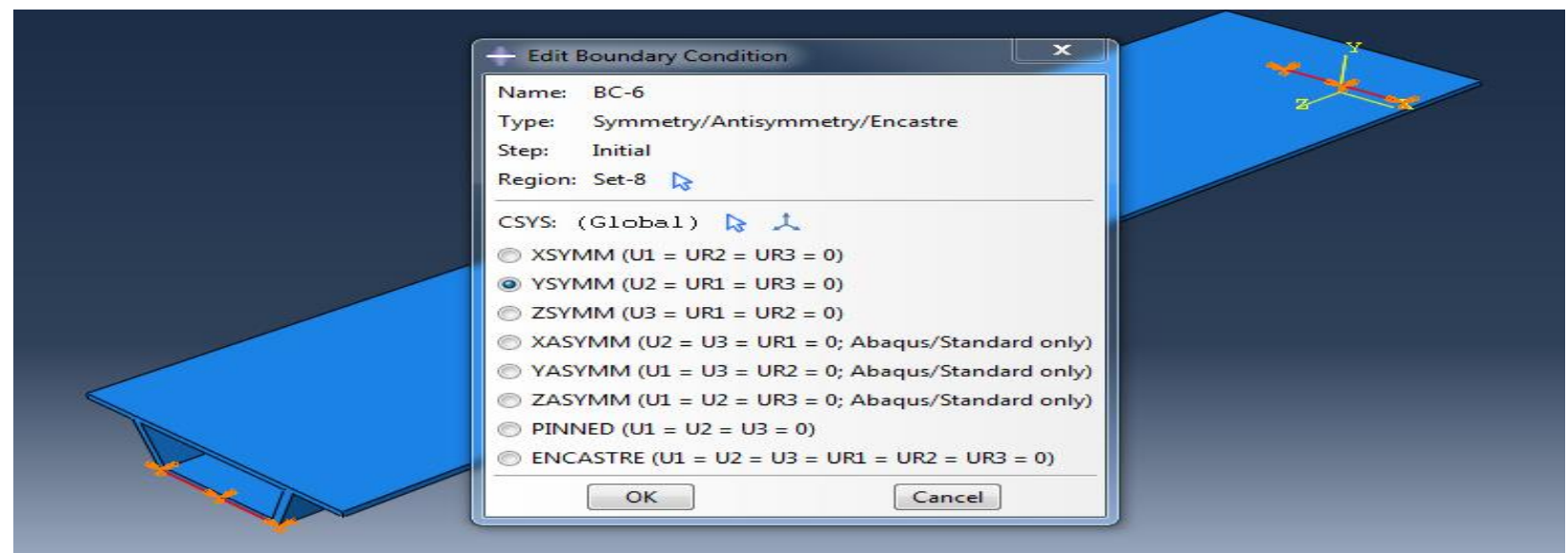

Figure 8. Boundary condition for the finite element model 


\subsection{Important Informations for Local Scouring}

To find out threshold value for local scour monitoring, the pier 8 would be taken because it has been reported that maximum vibration of the bridge occurred near pier 8 during a periodic monitoring with vibration sensors (Amin et al. 2015). They also found maximum scouring depth of $7 \mathrm{~m}$ near pier 8 during periodic monitoring leading the improper function of the Japan Bangladesh Friendship Bridge.

\subsection{Monitoring Local Scour}

Scouring is an important criterion for structural health monitoring in bridges especially for the bridges of Bangladesh. An investigation has showed that about $7 \mathrm{~m}$ scouring depth occurred in pier 8 of Japan Bangladesh Friendship Bridge causing an instable condition in the bridge (Amin et al 2015).

The SHM system applied on US59 over Guadalupe River Bridge in Texas, USA and San Antonio River Bridge, Texas, USA has been taken for monitoring scour depth in Japan Bangladesh Friendship Bridge. In US59 over Guadalupe River Bridge and San Antonio River Bridge, dual-axis tiltmeter was used on the second pier to measure tilt angle around flow direction axis and traffic direction axis. Two single axis tiltmeter were used on the deck to measure tilt angle around flow direction axis and traffic direction axis near pier 1 and 2 respectively. Two accelerometers were used on top of pier 1 and 2 but due to lots of power consumption, these were removed later.
Based on this, it has been decided to use one dual axis tiltmeter on the deck near pier 8 and another on pier 8 will be used and one accelerometer will be used on pier 8 . The dual axis tiltmeter would be able to measure tilt angle around flow direction and traffic direction axis. The equations proposed by Brioud et al. 2011 will be used as reference threshold value to give a check and closure information to the concerned authority of the bridge when excessive scouring is expected to take place.

\subsection{Tiltmeter Threshold Value}

There are four bridge failure modes due to scour i.e. 1) big scour hole, 2) settlement and rotation of the pier, 3) loss of the deck and 4) loss of the pier. According to Texas A\&M University, settlement and rotation of pier and big scour hole are two common results of scouring after studying 35 bridge failures.

These loss of pier and loss of deck actually occur due to two mechanisms: settlement of pier and rotation of pier. When the pier settles down too much, then the deck tilts which can be captured by tiltmeter placed on the deck. That's why a dual gauge tiltmeter is placed on the deck near monitored pier of Japan Bangladesh Friendship Bridge. The deck loses its support and falls down due to excess settlement of pier. The deck may lose its support also if the pier rotates too much resulting loss of deck and loss of pier shown in the Figure 9 and Figure 10 respectively.

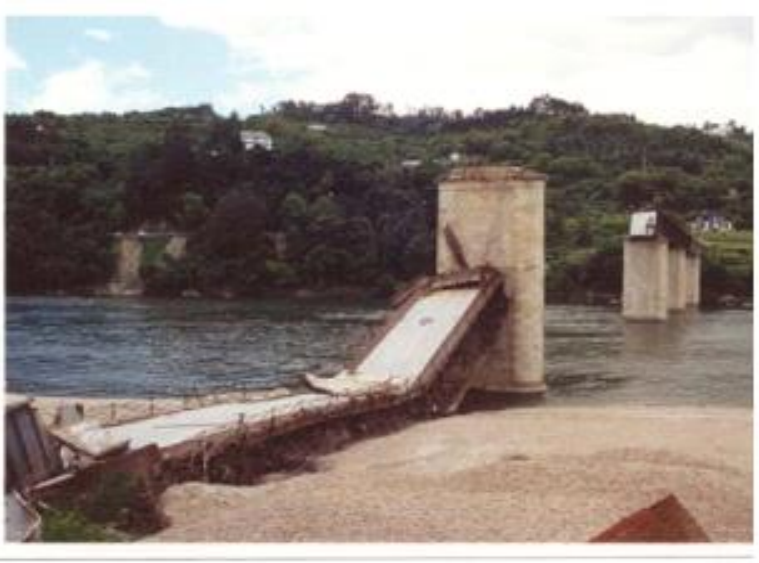

Figure 9. Loss of deck due to excess settlement of pier (Brioud et al. 2011)
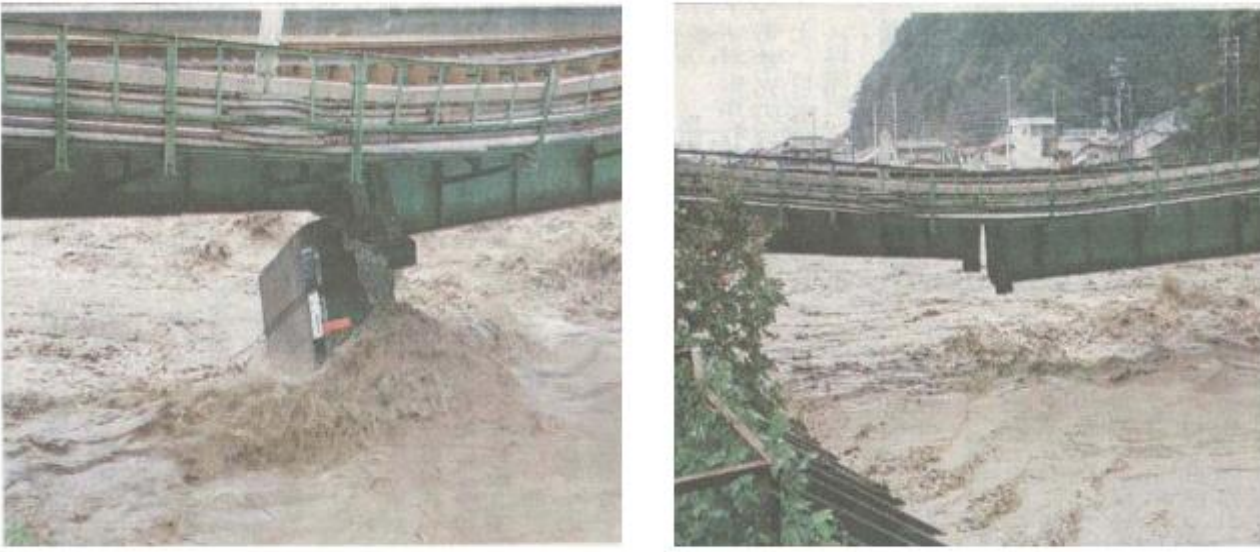

Figure 10. Loss of pier due to rotation of pier (Brioud et al. 2011) 


\subsubsection{Tiltmeter Placed on Top of Pier}

The dual gauge tiltmeter shown in Figure 11 placed on top of pier is capable to measure the rotation angle of pier around two direction of axis: flow direction axis and traffic direction axis. Based on the rotation angle, any possible scouring can be predicted which may cause danger.

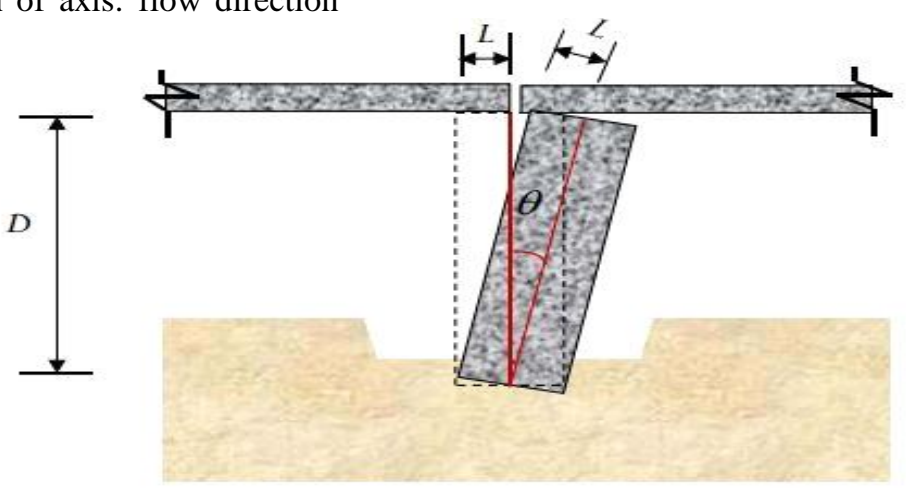

Figure 11. Tiltmeter threshold value calculation placed on top of pier 8 (Brioud et al 2011)

\subsubsection{Tiltmeter Placed On Deck}

The dual gauge tiltmeter shown in Figure 12 placed on top of pier is capable to measure the rotation angle of pier around two direction of axis: flow direction axis and traffic direction axis. Based on the rotation angle, any possible scouring can be predicted which may cause danger.

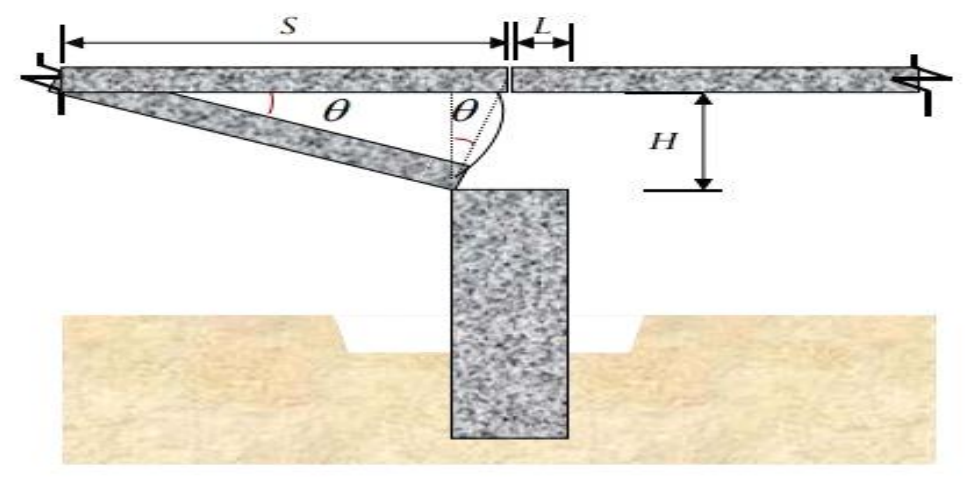

Figure 12. Tiltmeter threshold value calculation placed on deck near pier 8 (Brioud et al 2011)

\section{$4 \quad$ RESULTS}

\subsection{Thermal Stress from Finite Element Software \\ 4.1.1 CASE 1}

In case 1 (Figure 13), the top surface temperature was $317 \mathrm{~K}$ and bottom surface temperature was $304 \mathrm{~K}$.
Since the top surface temperature is higher than bottom surface, therefore the top surface would tend to expand subjected to tension and the bottom surface would tend to contract subjected to compression which is found from ABAQUS finite element analysis.

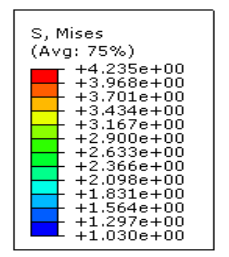

Step: Step-1

Step: Step-1
Increment
Primary Var: Step Time $=1.000$
Defformed

Primary Var: S, Mises
Deformed Var: U Deformation Scale Factor: $+3.807 e+01$

Figure 13. Thermal stress found from case 1 


\subsubsection{CASE 2}

In case 2 (Figure 14), the top surface temperature was $292 \mathrm{~K}$ and bottom surface temperature was $306 \mathrm{~K}$. Since the top surface temperature is lower than bottom surface, so the top surface would tend to contract subjected to compression and the bottom surface would tend to expand subjected to tension which is found from ABAQUS finite element analysis.
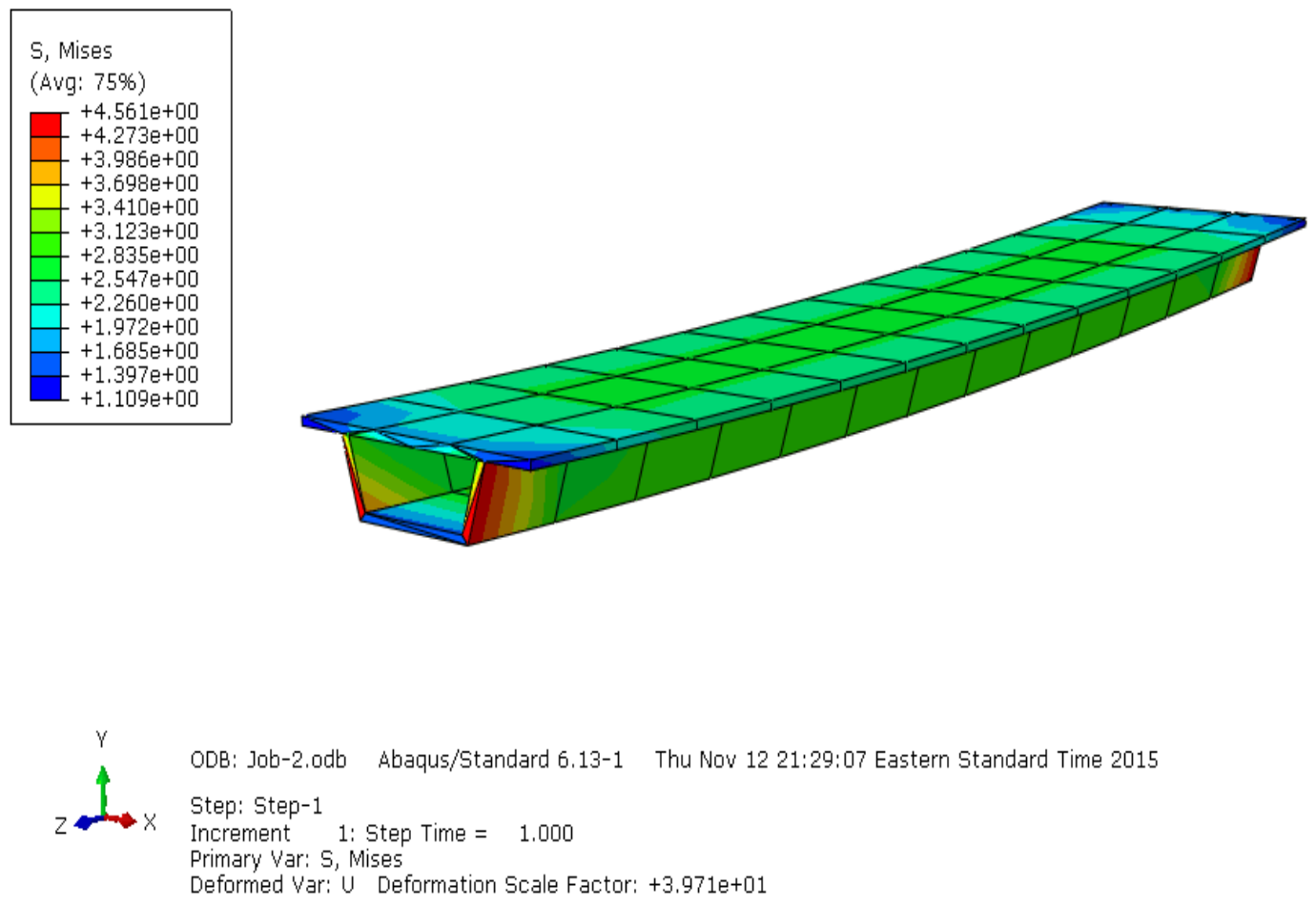

Figure 14. Thermal stress found from case 2

\subsubsection{CASE 3}

In case 3 (Figure 15), the top surface temperature was $306 \mathrm{~K}$ and bottom surface temperature was $294 \mathrm{~K}$. Since the top surface temperature is higher than bottom surface, therefore the top surface would tend to expand subjected to tension and the bottom surface would tend to contract subjected to compression which is found from ABAQUS finite element analysis.

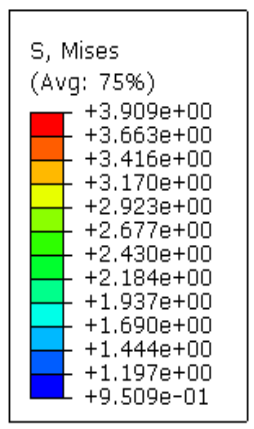

$$
\begin{aligned}
& 5 \text {, Mises } \\
& \text { (Avg: 75\%) } \\
& +3.909 \mathrm{e}+00 \\
& \begin{array}{l}
+3.663 \mathrm{e}+00 \\
+3.416 \mathrm{e}+00
\end{array} \\
& +3.170 \mathrm{e}+00 \\
& +2.923 \mathrm{e}+00 \\
& +2.430 \mathrm{e}+00 \\
& +2.184 \mathrm{e}+00 \\
& +1.937 \mathrm{e}+00 \\
& +1.444 \mathrm{e}+00 \\
& \begin{array}{l}
1.197 \mathrm{e}+00 \\
+9.509 \mathrm{e}-01
\end{array}
\end{aligned}
$$
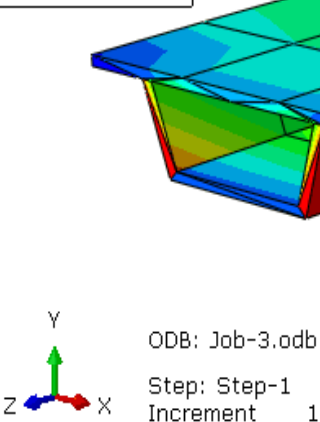

ODB: Job-3.odb Abaqus/Standard 6.13-1 Thu Nov 12 21:34:23 Eastern Standard Time 2015

Step: Step-1

Increment 1: Step Time $=1.000$

Primary Var: $S$, Mises

Deformed Var: U Deformation Scale Factor: $+3.945 e+01$

Figure 15. Thermal Stress found from case 3 


\subsubsection{CASE 4}

In case 4 (Figure 16), the top surface temperature was $286 \mathrm{~K}$ and bottom surface temperature was $294 \mathrm{~K}$. Since the top surface temperature is lower than bottom surface, so the top surface would tend to contract subjected to compression and the bottom surface would tend to expand subjected to tension which is found from ABAQUS finite element analysis.
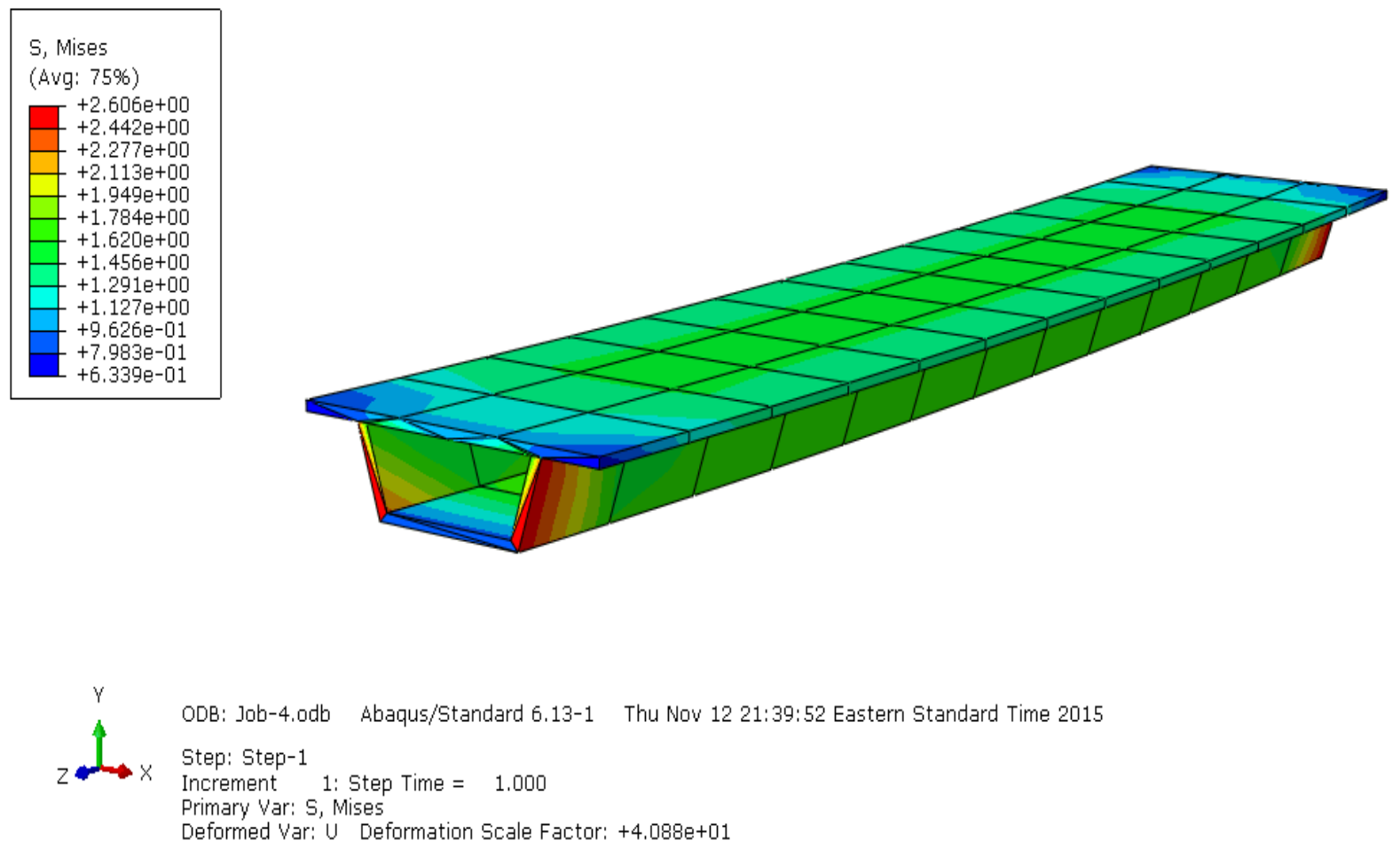

Figure 16. Thermal stress found from case 4

\subsection{Thermal Stress According To CHBDC (Canadian Highway Bridge Design Code)}

In Canadian Highway Bridge Design Code (CHBDC), there are some specification for allowable thermal stress. The calculation for case 1 based on CHBDC is discussed below:

In CHBDC, it has been mentioned to increase the maximum temperature by adding additional temperature $\delta \mathrm{T}$ where $\delta \mathrm{T}=6.25 \mathrm{~h}-2.5\left(0^{\circ} \mathrm{C} \leq \delta \mathrm{T} \leq 10^{\circ} \mathrm{C}\right)$

Here, $\mathrm{h}=$ depth of girder $=2.1 \mathrm{~m}$, in case of Japan Bangladesh Friendship Bridge

So, $\delta \mathrm{T}=(6.25 * 2.1)-2.5=10.625 \mathrm{~K}=10 \mathrm{~K}$

So, maximum temperature at top surface $=317+10=327 \mathrm{~K}$

In CHBDC, it has been mentioned to decrease the minimum temperature by subtracting additional temperature $\delta \mathrm{T}$, where $\delta \mathrm{T}=$ $1.75-4.375 \mathrm{~h}\left(-7^{\circ} \mathrm{C} \leq \delta \mathrm{T} \leq 0^{\circ} \mathrm{C}\right)$

So, $\delta \mathrm{T}=1.75-4.375 \mathrm{~h}=1.75-(4.375 * 2.1)=-7.4375=-7 \mathrm{~K}$

So, minimum temperature at bottom surface $=304-7=297 \mathrm{~K}$

Hence, thermal stress based on CHBDC $=(30000 * 12 \mathrm{E})-6 *(327-297)=10.8 \mathrm{MPa}$

In this way, thermal stress had been calculated for other cases and compared with analytical simulation which is shown in the following Table 5. 


\begin{tabular}{|l|l|l|}
\multicolumn{2}{l}{} & Table 5. Comparison of thermal stresses for four cases \\
\hline Case & $\begin{array}{l}\text { CHBDC } \\
\text { (MPa) }\end{array}$ & $\begin{array}{l}\text { Analytical Simulation } \\
\text { (MPa) }\end{array}$ \\
\hline Case 1 & 10.8 & 4.235 \\
\hline Case 2 & 11.16 & 4.561 \\
\hline Case 3 & 10.44 & 3.909 \\
\hline Case 4 & 9.00 & 2.606 \\
\hline
\end{tabular}

\subsection{Threshold Value for Local Scour Monitoring \\ 4.3.1 Tiltmeter Placed On Top of the Deck}

From Figure 12, it can be said that

$\operatorname{Sin} \Theta=\Theta=\frac{H}{S}, \mathrm{~S}=$ span of the bridge $=40 \mathrm{~m}, \mathrm{H}=$ settlement of the pier $=0.6 \mathrm{~m}($ Recommended $)$

$\Theta_{\text {check }}=\frac{H}{2 * S}$ and $\Theta_{\text {closure }}=\frac{H}{S}$ (Formulas proposed by Briaud et. al. $)$

$\Theta_{\text {check }}=0.1976^{\circ}$

Oclosure $=0.395^{\circ}$ for Japan Bangladesh Friendship bridge

\subsubsection{TILTMETER PLACED ON TOP OF THE PIER}

From Figure 11, it can be said that

$\operatorname{Sin} \Theta=\Theta=\frac{L}{D}, \mathrm{~L}=$ Supporting width between deck and pier $=3.2 \mathrm{~m}, \mathrm{D}=$ depth of pier $=40 \mathrm{~m}$

$\Theta_{\text {check }}=\frac{L}{4 * D}$ considering F.S. $=4$ and $\Theta_{\text {closure }}=\frac{L}{2 * D}$ considering F.S. $=2$ (Formulas proposed by Briaud et. al. $)[8]$

$\Theta_{\text {check }}=1.15^{\circ}$

$\Theta_{\text {closure }}=2.29^{\circ}$ for Japan Bangladesh Friendship bridge

\section{$5 \quad$ CONCLUSION}

\subsection{Findings}

a. The thermal stress found for case 1 is $4.235 \mathrm{MPa}$

b. The thermal stress found for case 2 is $4.561 \mathrm{MPa}$

c. The thermal stress found for case 3 is $3.909 \mathrm{MPa}$

d. The thermal stress found for case 4 is $2.606 \mathrm{MPa}$

e. Using the formulas proposed by Briaud et. al., it has been found that when the tilt angle is $0.1976^{\circ}$, it is needed to check local scouring near pier 8 and when the tilt angle is $0.395^{\circ}$, it warrants an emergency measures to check the scouring in order to prevent any accedents.

f. In case of tiltmeter placed on top of pier, it has been found that when the tilt angle is $1.15^{\circ}$, it is needed to check local scouring near pier 8 and when the tilt angle is $2.29^{\circ}$, it is needed to take an emergency measures.

\subsection{Scope for Future Investigation}

a. The pot bearing condition has been used in case of boundary conditions during performing analytical simulation because the bearing system in Japan Bangladesh Friendship Bridge is pot bearing. Other bearing systems can also be studied. b. Canadian Highway Bridge Design Code (CHBDC) has been used in order to check thermal stress. Other codes can also be checked.

\section{REFERENCES}

[1] Wardhana, K. and Hadipriono, F.C. (2003) "Analysis of Recent Bridge Failures in the United States." Journal of Performance of Constructed Facilities, Vol. 17, No. 3, 2003, pp.144-150

[2] Hansfard, M., Fleming, D., Paranhos, P. and Chrimes, M. "Portugese Bridge Disaster Blamed on Illegal Dredging", Portugese Bridge Disaster Blamed on Illegal Dredging, http://www.nceplus.co.uk/news/fast_news/?pid=2\&aid=13009\&si $\mathrm{d}=47 \&$ ChannelID $=4$

[3] Inaudi, D., Bolster, M., Deblois, R. (2009) "Structural Health Monitoring (SHM) System for the New I-35 St. Anthony Falls bridge". Proceedings of $4^{\text {th }}$ International Conference on Structural Health Monitoring on Intelligent Structure (SHM II-4), Zurich, Switzerland

[4] Swartz, R.A, Zimmerman A., Lynch J.P. (2007) "Structural health monitoring system with the latest information technologies". Proceedings of $5^{\text {th }}$ Infrastructure \& Environmental Management Symposium, Yamaguchi, Japan.

[5] Wang, Y., Lynch, J.P. and Law, K.H. (2007) "A wireless Structural Health Monitoring System with Multi-Threaded Sensing Devices: Design and Validation". Structure and Infrastructure Engineering, Vol. 3, No. 2, 2007, pp. 103-120

[6] Chen, Z., Guo, T., Yan, S. (2015) "Life-cycle Monitoring of Long-Span PSC Box Girder Bridges through Distributed Sensor Network: Strategies, Methods and Applications." Volume 2015, Article ID. 497159, 20 September 2014, 14 p. Retrieved from http://dx.doi.org/10.1155/2015/497159 
[7] Amin A.F.M.S., Okui Y. (2015). Design, construction and maintenance of bridges in Bangladesh: In the past, present and future. Proceedings of IABSE - JSCE joint conference on advances in bridge engineering - III, Dhaka, Bangladesh

[8] Briaud J.L., Chang K., Darby C., Hunt B.E., Hurlebaus S. Sharma H., Yao C., (Texas Transportation Institute). Real time monitoring of bridge scour using remote monitoring technology. Final report August 2008 - August 2010. Texas Department of Transportation: 2011. 414 p. Report No.: Report 0-6060 - 1. Contract No.: Project 0-6060. 